\title{
任意方向単純せん断におけるダイレイタンシーの統一的解釈
}

\section{A UNIFIED LAW FOR DILATANCY UNDER MULTI-DIRECTIONAL SIMPLE SHEARING}

\author{
福武毅 芳*・松岡 元** \\ By Kiyoshi FUKUTAKE and Hajime MATSUOKA
}

\begin{abstract}
Actual earthquakes generate complicated patterns of motions involving changes not only in amplitude but also in direction. In order to investigate the behavior under irregular pattern of shearing, several series of multi-directional drained simple shear tests on Toyoura sand were conducted by means of a simple shear test device incorporating two cyclic loading apparatus in two mutually perpendicular horizontal directions. Cumulative shear strain $G^{*}$ and resultant shear strain $\Gamma$ were introduced to find a unified law for dilatancy. And it was found that there exists a unique relationship between $G^{*}$ and volumetric strains with a parameter of $\Gamma$ independent of the shear strain history. Based on the arrangements of the test results, we find that the bowl-shaped slope, which compresses in accordance with $G^{*}$, exists in the strain space.
\end{abstract}

Keywords : dilatancy, multi-directional simple shearing, cumulative shear strain, resultant shear strain

\section{1. はじめに}

実際の地震の $\mathrm{S}$ 波による水平地盤での挙動は, 単純せ ん断変形に近く, しかも水平面における変位や加速度の 軌跡は Fig. 1 に示すようにランダムな経路を描く.よっ て，地震時の砂地盤の挙動を検討するには，水平面内で 任意方向へせん断したときの応力〜ひずみ〜ダイレイタ ンシー関係を算定する必要がある. しかし，従来の繰返 しせん断試験は, 三軸試験によるものが多く, また, 繰 返し単純せん断試験においても一方向の載荷に限られて いた。

このような中で, 軽部・福岡1) は水平二方向にせん断 できる静的単純せん断試験装置を用いて排水繰返しせん 断試験を行い, 一方向繰返しせん断よりも多方向繰返し せん断の方が圧縮しやすいことを示している。また， Pype, Seed, Chan ${ }^{2)}$ は振動台実験によって, 多方向振 動では一方向振動に比べて 2 倍の沈下が生じることを示 している.さらに，石原・山崎 ${ }^{3)}$, 時松・吉見 ${ }^{4)}$ は, 多 方向せん断の影響が液状化強度を低下させることを指摘

* 正会員 工修 清水建設 (株) 大崎研究室研究員 (元・名 古屋工業大学大学院生)

（テ100 千代田区内幸町 2-2-2 富国生命ビル 27F)

** 正会員 工博 名古屋工業大学教授 社会開発工学科 ( (466 名古屋市昭和区御器所町)

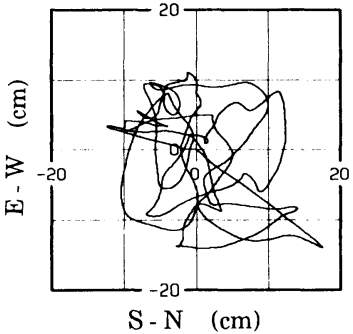

Fig. 1 Trajectory of displacement recorded in Hachinohe (Tokachi-oki earthquake, 1968).

している. よって, 水平面 (単純せん断面) 内における 多方向せん断の影響は大きく，ランダム方向の繰返しせ ん断時のダイレイタンシーの評価は重要であるといえ る.

そこで，本研究ではまず豊浦砂を試料として，任意方 向にせん断できる単純せん断試験機を用いて，回転経路 を含む種々の経路の排水繰返しせん断を行った。そして 上記の実験結果を統一的に検討するため，せん断ひずみ 経路の長さを表わす累加せん断ひずみ $G^{*}$ 之, 半径方向 の距離を表わす合せん断ひずみ $\Gamma$ とに着目した。この $G^{*}$ と $\Gamma$ を用いてダイレイタンシーを整理すれば，種々 の経路のダイレイタンシーが統一的に解釈できることを 


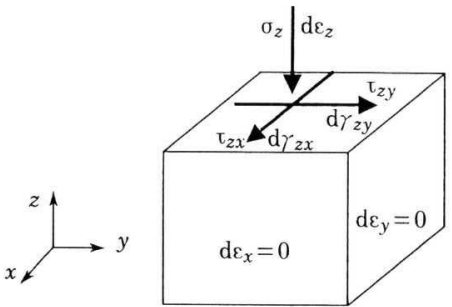

Fig. 2 Definition of stresses and strain increments.

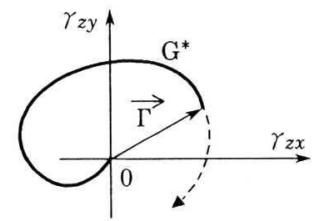

Fig. 3 The resultant shear strain $\Gamma$ and cumulative shear strain $G^{*}$.

示した.

\section{2. 諸量の定義}

多方向単純せん断において, $x, y, z$ 軸の方向および 応力やひずみ増分とそれらの正の方向を Fig. 2 のように 定義する．単純せん断においては側方は固定されている ため, $d \varepsilon_{x}=d \varepsilon_{y}=0$ である.したがって, 鉛直ひずみ $\varepsilon_{z}$ は体積ひずみに等しい。 また, 応力はすべて有効応力を 意味する。

任意方向へ単純せん断する場合のひずみ経路は,

Fig. 3 のように水平面（単純せん断面）内でランダムな ひずみ経路となる。そこで合せん断ひずみ $\Gamma$ と累加せ ん断ひずみ $G^{* 11}$ とを次式で定義する.

$$
\begin{aligned}
& \Gamma=|\vec{\Gamma}|=\sqrt{\gamma_{z x}^{2}+\gamma_{z y}^{2}} \ldots \ldots \ldots \ldots \ldots \ldots \ldots \ldots \ldots \ldots \ldots \ldots \ldots \\
& G^{*}=\sum \Delta G^{*}=\sum|\overrightarrow{\Delta \Gamma}|=\sum \sqrt{\Delta \gamma_{z x}^{2}+\Delta \gamma_{z y}^{2}} .
\end{aligned}
$$

$\Gamma$ は原点から半径方向の距離を表わし， $G^{*}$ はひずみ経 路に沿った長さを表わす.

水平面上のせん断・垂直応力比を次式で表わす.

$$
\begin{aligned}
& X_{z x}=\frac{\tau_{z x}}{\sigma_{z}}, \quad X_{z y}=\frac{\tau_{z y}}{\sigma_{z}} \cdots \cdots \ldots \\
& X_{z}=\left|\vec{X}_{z}\right|=\frac{\tau_{z}}{\sigma_{z}}=\frac{\sqrt{\tau_{z x}^{2}+\tau_{z y}^{2}}}{\sigma_{z}}
\end{aligned}
$$

\section{3. 任意方向単純せん断試験}

\section{（1）任意方向単純せん断試験機}

本研究で用いた任意方向単純せん断試験機(5) 7) の全景 をPhoto 1 に，また平面図と側面図を Fig. 4 に示す.形 式としてはNGI 型とほぼ同じであり, 石原らの二方向 単純せん断試験機 ${ }^{3)}$ を参考に作製した。供試体寸法は, 直径 $7 \mathrm{~cm}$, 高さ $2.7 \mathrm{~cm}$ の円柱形である.また, 摩擦の

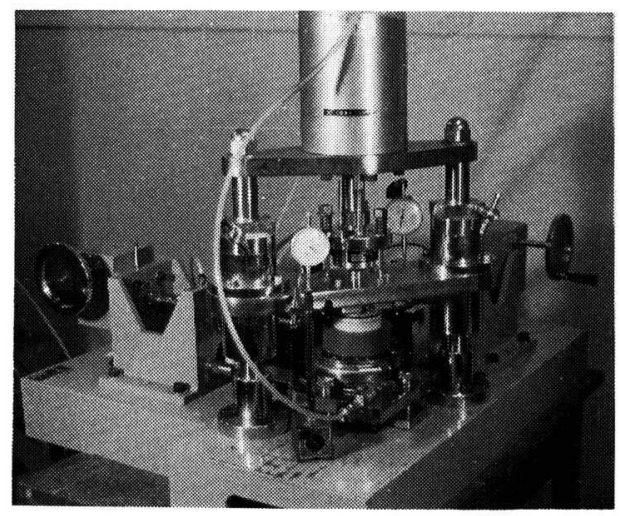

Photo1 Multi-directional simple shear apparatus.
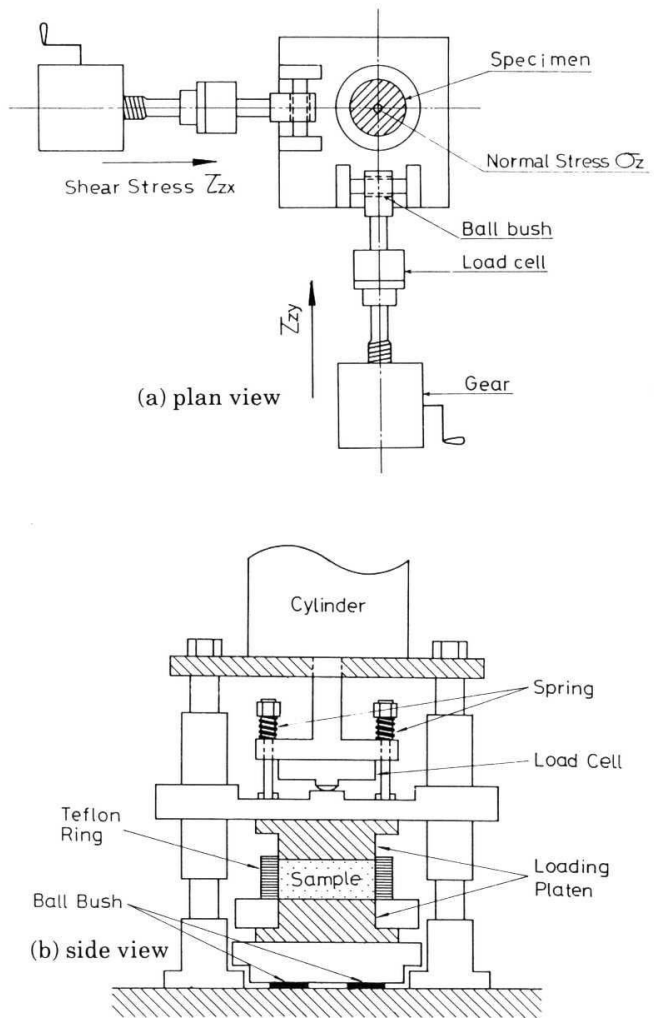

Fig. 4 Schematic illustration of the multi-directional simple shear apparatus.

非常に小さい薄い円形のテフロンリング 10 数枚を重ね て式料を拘束している。供試体の上下に取り付けるポー ラスストーンには直角二方向に金属の歯が付いており, 試料とポーラスストーンとの間ですべらないようにして ある.これによって, 合せん断ひずみ $\Gamma$ が $5 \%$ 程度ま でのせん断であればほぼ均一な変形が与えられる， が $5 \%$ を越える場合には，試料とポーラスストーンと の間ですべりが生じるので, 実験はやや信頼性に欠ける 
ものと思われる．鉛直応力 $\sigma_{z}$ は試料上部よりエアシリ ンダーを用いて載荷される. せん断応力 $\tau_{z x}, \tau_{z y}$ はエア シリンダーまたは手動ギアを用いてお互いに直交する二 方向（ $x$ 方向， $y$ 方向）から独立に載荷され，态力制御 でもひずみ制御でもせん断できる，せん断応力は試料下 部の可動板に加えられ，これがボールベアリングの上で 水平面上を任意方向に自由に動く.こうして任意方向の 繰返しせん断が可能となる. 試験中, $\varepsilon_{x}=\varepsilon_{y}=\gamma_{x y}=\tau_{x y}$ $=0$ であり， $\varepsilon_{z}, \gamma_{z x}, \gamma_{z y}, \sigma_{z}, \tau_{z x}, \tau_{z y}$ は測定できるが, $\sigma_{x}, \sigma_{y}$ は測定できない. したがって厳密な三次元応力下 での検討は困難である。

\section{（2）試料および供試体作製法}

用いた試料は煮沸により飽和させた豊浦砂 $\left(G_{s}=\right.$ $\left.2.65, e_{\max }=0.95, e_{\min }=0.58\right)$ である. 試料はスプー ンで二層に分けて流し込んだのち, 径 $5 \mathrm{~mm}$ のアルミ棒 で各層 30 回ずつ突いて作製した。 せん断直前の間隙比 $e_{0}$ は $0.69 \sim 0.73$ である.

\section{（3）実験方法}

実験は, まず所定の鉛直応力 $\sigma_{z}$ のもとで $K_{0}$ 圧密する. $K_{0}$ 圧密終了時の鉛直応力は, 以後, 断りのない限り $\sigma_{z}$ $=200 \mathrm{kN} / \mathrm{m}^{2}$ である. 引き続く排水せん断では， $\sigma_{z}$ を そのまま一定値に保ってせん断する。

\section{4. 任意方向単純せん断のダイレイタンシー特 性}

一般に土の体積ひずみ増分 $d \varepsilon_{z}$ は，せん断によるひず み增分 $d \varepsilon_{z}^{s}$ 亡圧密によるひずみ増分 $d \varepsilon_{z}^{c}$ とに分けられ る.ここで, 肩文字 ' $s$ ' はせん断成分を, ' $c$ ' は圧密成 分を意味している， $d \varepsilon_{z}^{s}$ は有効鉛直応力 $\sigma_{z}$ が一定のも 亡でせん断したよきのダイレイタンシーのことであり, $d \varepsilon_{z}^{c}$ は $\sigma_{z}$ の変化により生ずるひずみのことをいう. 行っ た実験は，すべて $\sigma_{z}$ が一定のもとでの排水せん断試験 であるため，以下ではダイレイタンシー $d \varepsilon_{z}^{s}$ の特性に ついて考察している. また，以下の記述に現われる $x$ 方向（ $y$ 方向）への載荷とは, Fig. 2 に示す $x$ 方向 $(y$ 方向）にせん断応力 $\tau_{z x}\left(\tau_{z y}\right)$ を載荷することを意味して いる。

\section{（1）応力制御による直角二方向載荷試験}

Fig. 5 に示すようなせん断応力経路で, $y$ 方向へ載荷 除荷した後, $x$ 方向に載荷する応力制御の二方向せん断 を行った.このときの $\gamma_{z y} \sim \gamma_{z x}$ 平面における $x$ 方向載 荷（第二載荷）時のせん断ひずみ経路を Fig. 6 に示す. この図より, $y$ 方向に載荷除荷したとき $7.5 \%$ 程度の 残留ひずみが残っており，次にこの状態から $x$ 方向に 載荷すると，せん断ひずみ経路が $y$ 軸の負の方向にず れる傾向がみられる.この現象は次のようなものをイ メージすると理解しやすい.

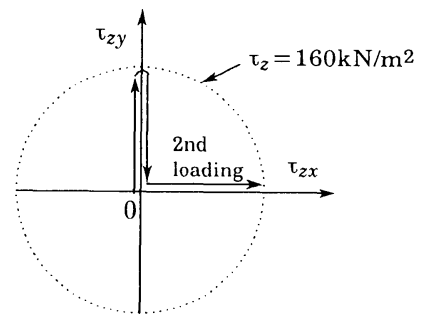

Fig. 5 Loading path in two-directional shearing.

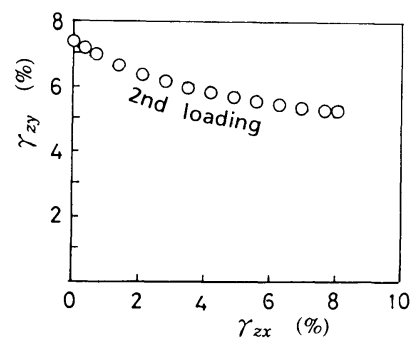

Fig. 6 Shear strain path in second loading to $x$-direction.

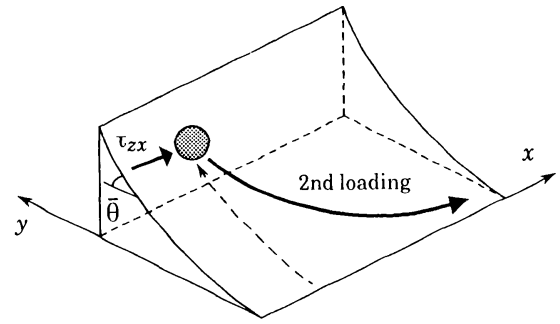

Fig. 7 Soil particle which is sheared with slipped down the slope.

$y$ 方向に載荷除荷したときの平均的な土粒子の状態 は, $y$ 方向へ上り勾配をもつ粒子接点角が卓越している 状態にあると考えられる。これは土粒子が $y$ 方向載荷 で形成された斜面に土粒子がまだとゼまっている状態に 対応する.このときの斜面の角度 $\bar{\theta}$ は，単純せん断面 における粒子接点角の平均的な值に対応すると思われ る.そのような状態のところへ第二載荷として $x$ 方向 へせん断応力 $\tau_{z x}$ を載荷すれば，土粒子は Fig. 7 のよう に, $y$ 方向の第一載荷で形成された斜面をすべり降りな がらせん断されることになる．そしていずれは $x$ 方向 に斜面を形成し再び膨張し始めるであろう。このように 解秎すれば，第二載荷時のせん断ひずみ経路が Fig. 6 の ような曲線になることは納得できる。また，もし同様な 二方向せん断を $x$ 方向と $y$ 方向との順序を逆にして 行っても，同様な解釈が成り立つであろう。すなわちこ のような斜面は放射上のあらゆる方向で考えることが可 能である. よってこのような斜面を三次元的に拡張して 考えると，「おわん」のような回転体の斜面が存在する 


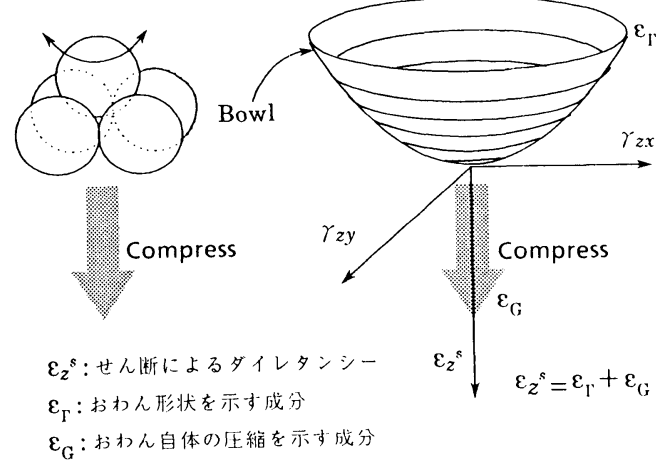

Fig. 8 The "bowl" in strain space and its microscopic image.

ものと仮想される.

（2）ひずみ空間において圧縮してゆく「おわん」」),9) 上記のような粒子接点角を反映した斜面上での粒子の 動きは，物理空間におけるイメージであった。ここでは このイメージを Fig. 8 に示すようにせん断ひずみと体積 ひずみ $\left(\right.$ 鉛直ひずみ $\left.\varepsilon_{z}^{s}\right)$ を軸とするひずみ空間におい て仮定してみる.すなわち Fig. 8 に示すように，ひずみ 空間において「おわん」のような回転体の斜面が存在す るものと仮定する．このとき，おわんの接平面のなす立 体角は単純せん断面における平均的な粒子接点角を表わ し, 原点からの距離がせん断ひずみと体積ひずみに対応 することになる．任意方向へのせん断時には，平均的な 土粒子接点はこのおわん上を動くことになる．またこの とき同時におわん自体もせん断による靦乱とともに体積 ひずみ方向 ( $z$ 方向) に圧縮してゆくものと考えられる. このような仮定に基づけば，結果的に観測されるせん断 による体積ひずみ $\varepsilon_{z}^{s} は$, おわん上を登り降りする成分 とおわん自体が圧縮してゆく成分とを重ね合わせたもの であるよ解釈される。このような多方向単純せん断の解 积は, Fig. 8 の左図に示すように土粒子が平均的に他の 土粒子の間に落ち込んだりあるいは乗り上げたりしなが ら全体的に圧縮してゆくことに対応していると思われ る.

ここでおわん上を登り降りする成分，すなわちおわん の底からあるところまでの高さを表わす成分を $\varepsilon_{r}$ とし， おわん自体がせん断による摜乱とともに圧縮してゆく成 分を $\varepsilon_{G}$ とすれば, 体積ひずみ $\varepsilon_{z}^{s}$ は， $\varepsilon_{\Gamma}$ と $\varepsilon_{G}$ との重ね 合わせ ; $\varepsilon_{z}^{s}=\varepsilon_{\Gamma}+\varepsilon_{G}$ として表現できる.おわんの形を $\varepsilon_{z}^{s}$ 軸 $\left(\gamma_{z x}=\gamma_{z y}=0\right)$ を中心とする回転体と仮定すれば, $\varepsilon_{\Gamma}$ は合せん断ひずみ $\Gamma$ のの関数で表現できる（ $\varepsilon_{\Gamma}=$ $\left.f_{1}(\Gamma)\right)$. また, おわん自体の圧縮成分 $\varepsilon_{G}$ は瀶乱の関数 $\left(\varepsilon_{G}\right.$ $=f_{2}($ 摫乱)）亡考えられる. (ま，摫乱を表わす指標之 して累加せん断ひずみ $G^{*}$ を考えれば, $\varepsilon_{G}=f_{2}\left(G^{*}\right)$ のよ うに $G^{*}$ の関数として定式化できるものと思われる. そ
こで, ここでは, $\varepsilon_{\Gamma}, \varepsilon_{G}$ を $A, B, C, D$ を係数として次 式で仮定する.

$$
\begin{aligned}
\varepsilon_{r} & =A \cdot \Gamma^{B} \ldots \ldots \\
\varepsilon_{G} & =\frac{G^{*}}{C+D \cdot G^{*}}
\end{aligned}
$$

$\varepsilon_{\Gamma}$ 成分は, 粒子がおわんのどの高さのところに存在 するかを示すもので，おわんの底を基準にして常に膨張 側の成分を表わす．微視的には粒子よ゙うしの乗り上がり を表わしている (Fig. 8 参照)。これに対して $\varepsilon_{G}$ 成分は， 摫乱とともに粒子構造の弱点部分が崩れ収縮安定化し, 全体が圧縮してゆくことを示す成分である．この $\varepsilon_{G}$ 成 分は繰返しせん断時のダイレイタンシーの基盤となる重 要な成分でマスターカーブ的なものであり， $\varepsilon_{r}$ 成分は それに付随する波打ち成分である．また， $\varepsilon_{G}$ 成分は双 曲線亡仮定しているため, 粒子構造の弱点部分の圧縮変 形はせん断の初期において特に影著であり，せん断によ る摫乱がある程度継続すれば，粒子構造は全体的に安定 化し $\Gamma=0$ でのダイレイタンシーはやがて最終圧縮量 $1 / D$ (これは双曲線の漸近線）に落ち着くことを示して いる.

よって，このような性質をもつ $\varepsilon_{\Gamma}$ と $\varepsilon_{G}$ との和として ダイレイタンシーを表現しているということは,「ダイ レイタンシーは, 粒子どうしの乗り上がりによる膨張す る過程と, 構造の相対的に弱いところが崩れ収縮してゆ く過程との兼衫合いで決まる」と解积していることにな る.

以上の重ね合わせ法則に基づいて体積ひずみ $\varepsilon_{z}^{s}$ は結 局次式で表わされる。

$$
\varepsilon_{z}^{s}=\varepsilon_{\Gamma}+\varepsilon_{G}=A \cdot \Gamma^{B}+\frac{G^{*}}{C+D \cdot G^{*}}
$$

上式よりせん断ひずみ $\left(\Gamma, G^{*}\right)$ 体積ひずみ $\left(\varepsilon_{z}^{s}\right)$ 関係が

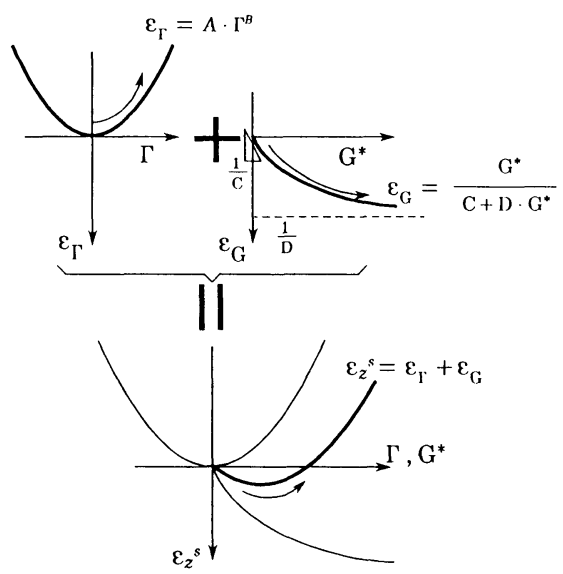

Fig. 9 Superposition of $\varepsilon_{\Gamma}$ and $\varepsilon_{G}$ in the case of uni-directional simple shearing. 
求まったことになる.

Fig. 9 には, 単調載荷の場合の上式の重ね合わせ法則 $: \varepsilon_{z}^{s}=\varepsilon_{\Gamma}+\varepsilon_{G}$ を示す. $\varepsilon_{z}^{s}$ の最大圧縮点は，おわんを登 る成分の増分 $\Delta \varepsilon_{\Gamma}$ 之，おわん自体が圧縮する成分の増 分 $\Delta \varepsilon_{G}$ とがちょうどバランスした状態 $\left(\Delta \varepsilon_{\Gamma}+\Delta \varepsilon_{G}=0\right)$ であると考えられる.

Fig. 10 には，一方向繰返しせん断の場合を示す。途 中の@点で逆振りせん断した場合を考えると, 粒子はそ れまでおわんを登っていたのが，こんよ゙は下ることにな り，かつおわん自体も $G^{*}$ とともに圧縮してゆくので, ダイレイタンシーの形は, 第一載荷と比べてだらだらと よく圧縮することになる. 引き続きそのまません断して
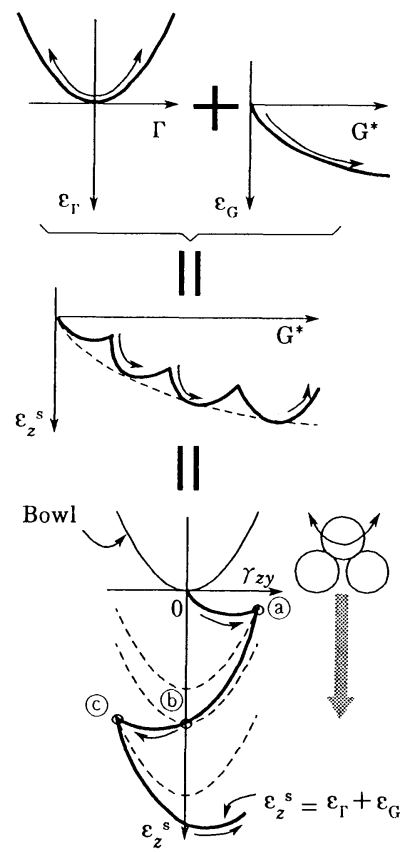

Fig. 10 Dilatancy in the case of repeated uni-directional simple shearing.

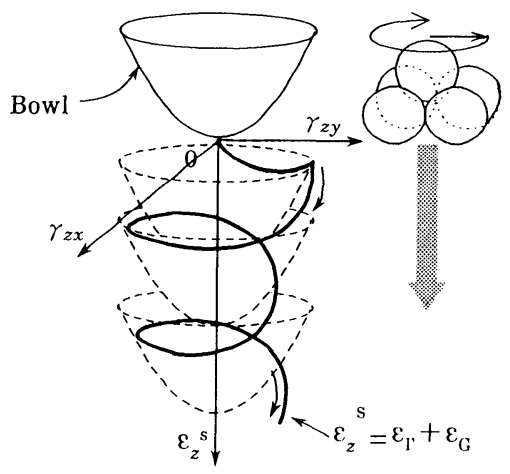

Fig. 11 Dilatancy in the case of repeated circular simple shearing. ゆけば，粒子はいずれはおわんの底を通り過ぎ（b点） またおわんを登ることになる。そして $\Delta \varepsilon_{\Gamma}$ が $\Delta \varepsilon_{G}$ をし のぐとき再び膨張してくる (c)点). 以下何回も繰返し せん断を行えば上記のことを繰り返して波打ちながら圧 縮してゆくことになる. 繰返しせん断におけるこのよう な重ね合わせを用いたダイレイタンシーの算定法は,

Fig. 11 に示すように, 円経路せん断はもとより全くラ ンダムな経路における繰返しせん断においてもそのまま 適用できる.

また緩詰め, 密詰めのダイレイタンシー特性の差異は, $\varepsilon_{G}$ と $\varepsilon_{\Gamma}$ との相対的な大きさの割合で表現できる.たと えば，非常に緩い砂や粘土のように構造的に弱点の卓越

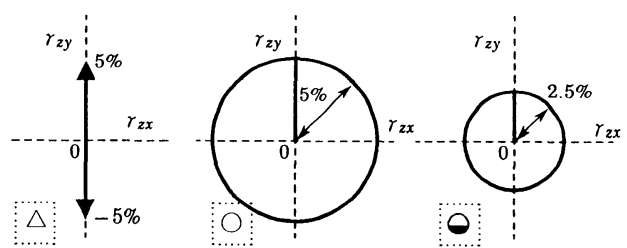

(a) 直線 $\gamma_{z y}= \pm 5 \%$

(b) 円 $\Gamma=5 \%$

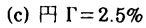

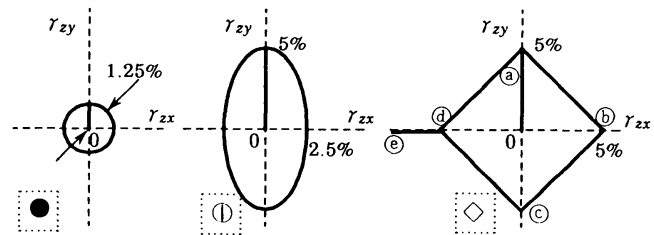

$\begin{array}{ll}\text { (d) } \text { 円 } \Gamma=1.25 \% & \text { (e) 梢円 }\end{array}$

(几四角形

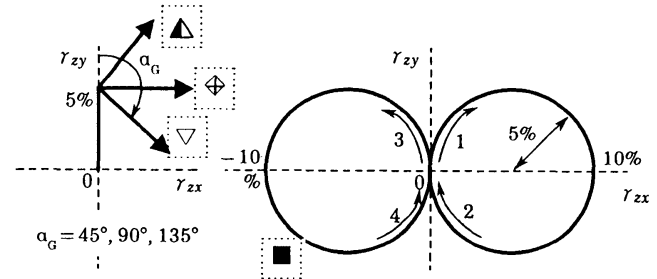

(g) 折れ線

(h) 8 の字

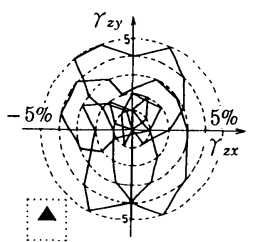

(i) ランタム

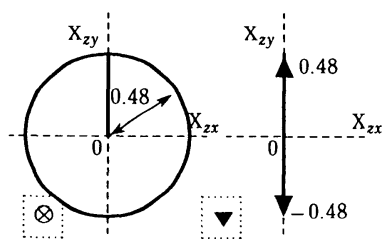

(j) 円 $\mathrm{X}_{z}=0.48$ (k) 直線

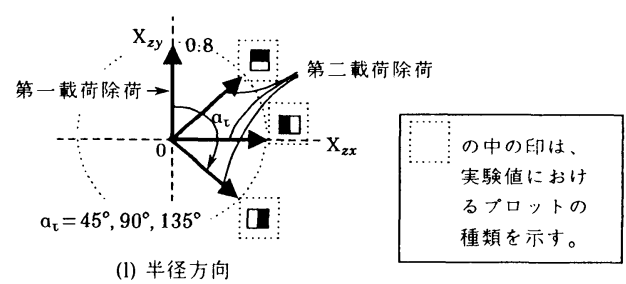

Fig. 12 Various loading paths in simple shear tests. 
する土では, 圧縮成分 $\varepsilon_{G}$ が卓越し膨張成分 $\varepsilon_{r}$ が相対的 に小さいため, ダイレイタンシーの形はほとんど $\varepsilon_{G} そ$ のものとなる.

\section{5. 排水繰返しせん断試験による検証}

ここでは,前節のようなダイレイタンシーの考え方を， 種々の経路における排水せん断試験結果をもとに検証す る.

まず Fig. 12(b)，(c)，(d) に示すように $\Gamma=5 \%$, $2.5 \% ， 1.25 \%$ なる 3 種類のひずみ円経路に沿ってせ ん断した場合の実験データについて考察する.この実験 では，第一載荷として半径方向に所定の $\Gamma$ となるまで せん断した後，円経路に沿って右回りにせん断するもの である. ただし， $\Gamma=1.25 \%$ の場合は途中の 3 周目 $\left(G^{*}\right.$ $=17 \%$ ）加逆回り（左回り）となっている.

ひずみ円経路せん断では， $\Gamma=$ 一定であるから $\varepsilon_{\Gamma}$ 成 分が一定となり，マスターカーブ $\left(G^{*} \sim \varepsilon_{G}\right.$ 関係 $)$ に平 行な滑らかな曲線に沿って圧縮することになる.よって, ひずみ空間におけるダイレイタンシーの軌跡は Fig. 11 に示すようにらせん状になるものと思われる。このダイ レイタンシーを $G^{*} \sim \varepsilon_{z}^{s}$ 関係で整理したのが Fig. $13 て ゙$ ある．「の大小にかかわらず，また途中で回転方向が 変わっても $\varepsilon_{z}^{s}$ が $G^{*}$ に対して 滑らかでお互いに平行な曲線に 沿って圧縮してゆくのがわか る. またお互いの曲線間の距離 はそれぞれの $\varepsilon_{\Gamma}$ 成分の差異に よるものであると考えられる.

次に Fig. 12 に示すすべての 経路に沿ってせん断した場合の 種々の実験データについて検討 する.ただし，(a)〜(i) はひ ずみ制御の実験であり, $(\mathrm{j})$ (1) は応力制御の実験である. これらすべての実験データを $G^{*} \sim \varepsilon_{z}^{s}$ 関係で整理しても，お のおのの $\varepsilon_{\Gamma}$ 成分がさまざまな ためにばらばらになってしま う. そこで， $\Gamma=5 \%, 2.5 \%$, $0 \%$ の 3 つに着目し， $\varepsilon_{\Gamma}$ 成分 を固定して各種の実験データを 整理すれば，Fig.14に示すよ うにそれぞれユニークに整理さ れる.図中のプロットの種類は, 載荷経路の違いにより区別して おり Fig.12中に示してある. 同図よりいかなる経路のせん断
試験結果も $\Gamma=$ 一定 $\left(\varepsilon_{\Gamma}\right.$ 成分=一定 $)$ で整理してやれば, $G^{*} \sim \varepsilon_{z}^{s}$ 関係が 1 本の曲線で整理されることがわかる.

また，Fig.12の経路の実験における体積ひずみのう ち, $G^{*}=$ 一定 $=10 \%\left(\varepsilon_{G}\right.$ 成分＝一定）における体積ひ ずみを $\Gamma$ に対して整理すると，Fig. 15 のようにユニー クに整理される。この曲線は $G^{*}=10 \%$ における $\varepsilon_{r}$ 成 分を表わしており，この形そのものがおわんの形を表わ している.すなわち，Fig. 15 で表わされるおわんが, Fig. 14 のように $G^{*}$ とともに圧縮してゆくことになる. 以上の実験結果より, 式 ( 7 ) がせん断経路のいかん を問わず成り立つことが検証された。

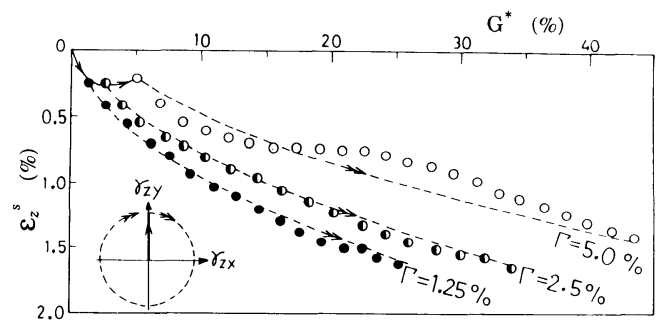

Fig. 13 Relation between $G^{*}$ and $\varepsilon_{z}^{s}$ in circular shear strain path.

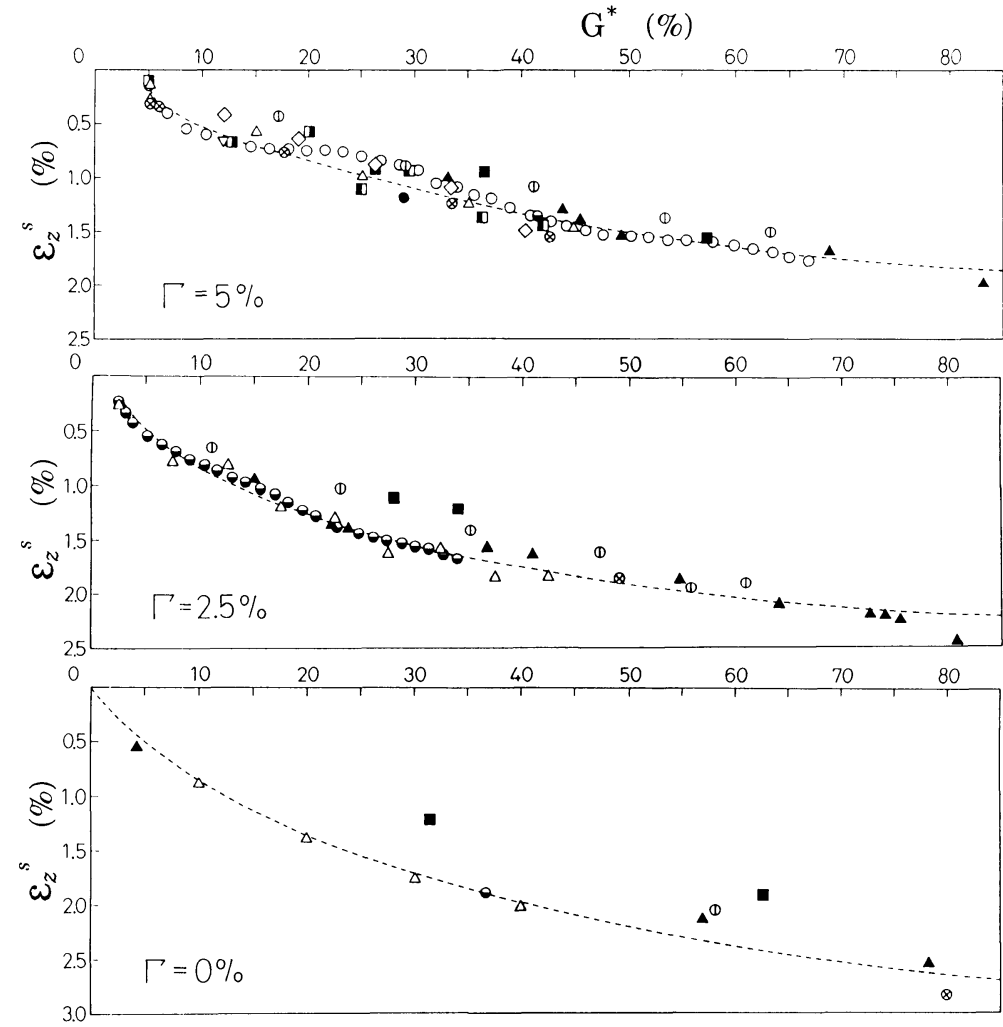

Fig. 14 Relation between $G^{*}$ and $\varepsilon_{z}^{s}$ in various loading path (at $\Gamma=5 \%, 2.5 \%, 0 \%$ ). 


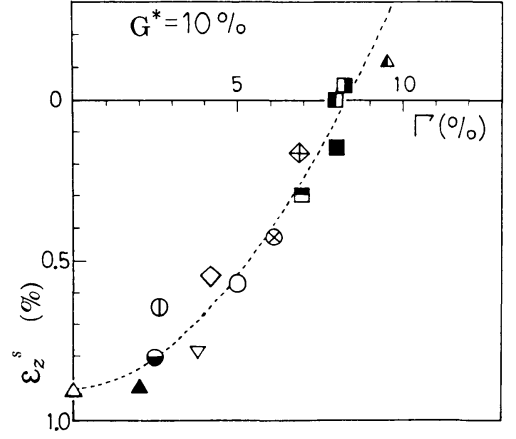

Fig. 15 Relation between $\Gamma$ and $\varepsilon_{z}^{s}$ in various loading path (at $G^{*}=10 \%$ ).

6. 合せん断ひずみ $\Gamma$ をパラメーターとした ときの累加せん断ひずみ $G^{*}$ と体積ひずみ $\varepsilon_{z}^{s}$ との関係

上記のような実験結果より， $G^{*} \sim \varepsilon_{z}^{s}$ 関係には Fig. 16 に示すような $\Gamma$ をパラメーターとした曲線群が存在す るものと思われる，すなわち，一定の $\Gamma$ に着目（おわ んの同じ高さに着目) すれば $G^{*}$ が大きいほど圧縮量が 大きい.Fig. 17 に示すように，一方向繰返しせん断試 験のデー夕を同じ $\Gamma$ における $\varepsilon_{z}^{s}$ を連ねることによって も，これらの曲線群を得ることができる．これらの曲線 群のうち, $\Gamma=0 \%$ における曲線はおわんの底の軌跡を 表わすため, $\varepsilon_{z}^{s}$ の最大値に相当する. よって, 式 $(6)$

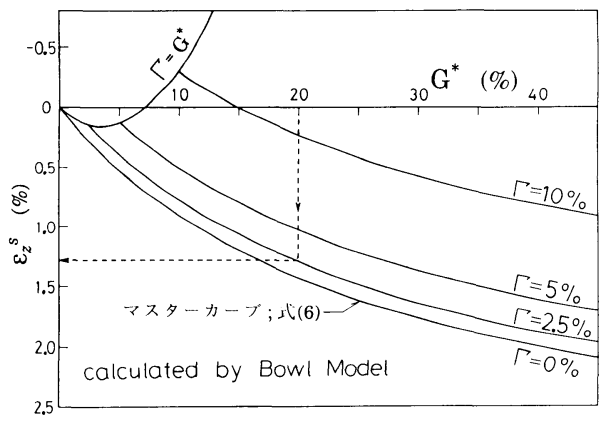

Fig. 16 Relation between $G^{*}$ and $\varepsilon_{z}^{s}$ with parameter of $\Gamma$.

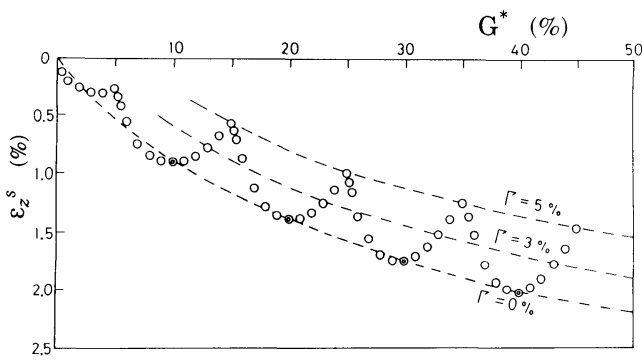

Fig. 17 Method for determining curves with constant $\Gamma$ from the data of uni-directional simple shear test.
のマスターカーブは一方向繰返しせん断において,$\Gamma=$ $0 \%$ における $\varepsilon_{z}^{s}$ を連ねることによって得られる. $\Gamma=$ $G^{*}$ の曲線は半径方向単調載荷の場合のダイレイタン シーであり,最もよく膨張する場合に相当する.したがっ て, Fig.16のような $G^{*} \sim \varepsilon_{z}^{s}$ 関係において，いかなる経 路のせん断においても，ダイレイタンシーは必ず $\Gamma=0$ $\%$ の曲線と $\Gamma=G^{*}$ の曲線との間に存在することにな る.

ここで Fig. 16 の曲線群が一方向繰返しせん断試験な よ゙から得られたとする. そして Fig. 18 に示すようなあ る任意のひずみ経路を考え, 点@までの累加せん断ひず み $G^{*}$ と合せん断ひずみ $\Gamma$ とがたとえば $G^{*}=20 \%, \Gamma$ $=2.5 \%$ とすれば, Fig. 16 中の破線の矢印で示してい るように, @点での体積ひずみは簡単に求めることがで きる.

ところで, Fig. 12 のデータのうち, 振幅 $\gamma_{z y}= \pm 5 \%$ の直線経路せん断と $\Gamma=5 \%$ の円経路せん断の試験結 果に着目すると, 1 周期当たりの $G^{*}$ は円経路せん断の 方が $(2 \pi \times$ 半径 $) /(4 \times$ 半径 $)$ 倍 $=1.57$ 倍長い. よって 体積ひずみ $\varepsilon_{z}^{s}$ を繰返し回数 $N$ で整理すれば, 円経路せ ん断の方がよく圧縮することになる. Fig. 19 は, 直線 経路（ $\Delta$ 印）亡円経路（○印）のせん断試験の $\Gamma=5 \%$ での $\varepsilon_{z}^{s}$ を繰返し回数 $N$ に対してプロットしたものであ る.やはり円経路せん断試験の体積ひずみの方がよく圧 縮しており， $G^{*}$ に対してユニークに整理できたダイレ イタンシーも， $N$ に対してはユニークに整理できな (101011)ことになる.ただし, 直線経路のせん断試験では, おわんの底を通るので, 図中の破線のように波打ちなが ら圧縮する．よって，N が小さいときは部分的に直線

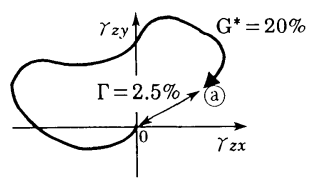

Fig. 18 Shear strain path.

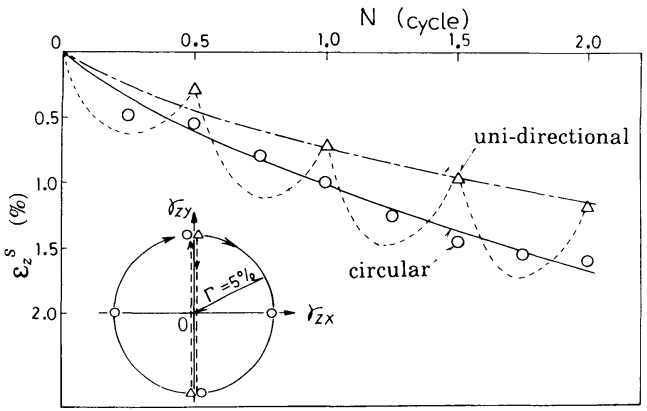

Fig. 19 Relation between $N$ and $\varepsilon_{z}^{s}$ at $\Gamma=5 \%$. 
経路の方が良く圧縮することもあるので注意を要する. なお, 円経路せん断では直線経路せん断よりも体積ひず みが 1.5 倍程度よく王縮する傾向は, 松岡ら ${ }^{12)}$ が三主応 力制御試験機を用いて行った正八面体面上の応力経路に おいても示されているのは興味深い.このような傾向よ り, 液状化問題においては, 一方向せん断よりも多方向 せん断の方が危険であるといえる。

\section{7. ダイレイタンシーの計算例}

ここでは, 式（7）に示す提案したダイレイタンシー モデルに基づいた計算結果を示し, 実験結果と比較する. 対象とした実験は,Fig.12の（a）に示す一方向繰返し せん断と（i）に示すランダムなひずみ経路でのせん断 試験結果である.（i）は, 実際の地震の水平面上の変位 軌跡を意識して行った試験であり，その経路は折線で あって折れ曲がり点では $\Gamma$ がちょうど $0 \%, 1 \%, 2 \%$, $3 \%, 4 \%, 5 \%$ となっている.

用いたパラメーターは, 一方向繰返しせん断試験結果 より決定した。すなわち, 式（6）のマスターカーブに 関与するパラメーター $C, D$ については, Fig. 20 に示 すように $G^{*} \sim G^{*} / \varepsilon_{z}^{s}$ の直線関係から決定した. パラ メーター $A, B$ については, マスターカーブである $\varepsilon_{G}$ 成分を決定後に, $\varepsilon_{z}^{s}$ のカーブフィッティングより決定 した. カーブフィッティングは， $\varepsilon_{z}^{s} よ り \varepsilon_{G}$ 成分を差し 引いた成分について行った，用いた值は， $A=-0.03$, $B=1.6, C=8.0, D=0.3$ である. Fig. 16 に示す曲線は, このパラメーターを用いた式（ 7 ）の計算曲線であり，

Fig. 13, 14 の実験結果と良く一致している.

Fig. 21 には, 一方向繰返しせん断とランダムひずみ 経路（Fig. 12(i)）のせん断試験の実測値と計算値との
比較を示す．ランダム経路の実験では, ひずみ経路の折 れ曲がり点の值をプロットしており, 図中の実線は単に そのプロットを結んだものである.計算值も同様である. 実測值も計算值も $\Gamma$ が同じところでの結果はプロット の形を同じにしてある．実測值において注目すべきは， 一見ランダムに圧縮してゆくようにみえる体積ひずみ も，「が同じところでみてやれば 1 本の滑らかな曲線 となることである，たとえば， ロプロットを連ねると波 打たない滑らかな 1 本の曲線となる。このように全くラ ンダムな経路においても， $\Gamma$ をパラメーターとした曲 線が存在することは興味深い.

また，このダイレイタンシー計算法に基づけば, よ゙の ようなせん断経路においてもマスターカーブ $\left(G^{*} \sim \varepsilon_{G}\right)$ は 1 本となる. マスターカーブは式 $(6)$ より $G^{*} \rightarrow \infty$ で $\varepsilon_{G} \rightarrow 1 / D$ となる. したがって, 一方向の数回の繰返 しせん断試験のデータを Fig. 20 のように整理し，その 直線の傾き $(D)$ を求めれば, 任意経路で多数回繰り返し たときの最大圧縮量 $(1 / D)$ は予測できることになる.

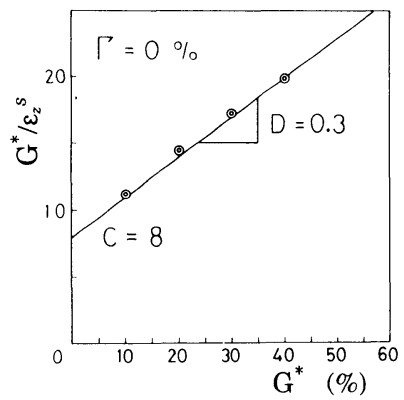

Fig. 20 Determination method of $C$ and $D$ by relation between $G^{*}$ and $G^{*} / \varepsilon_{z}^{s}$.

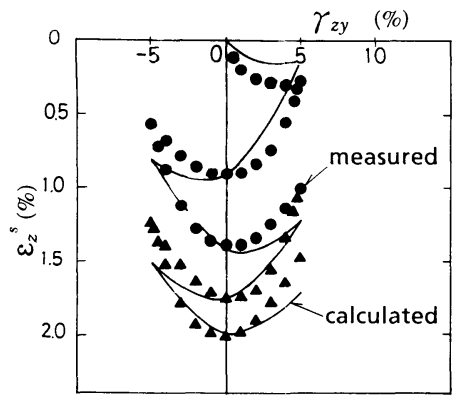

(a) uni-directional path

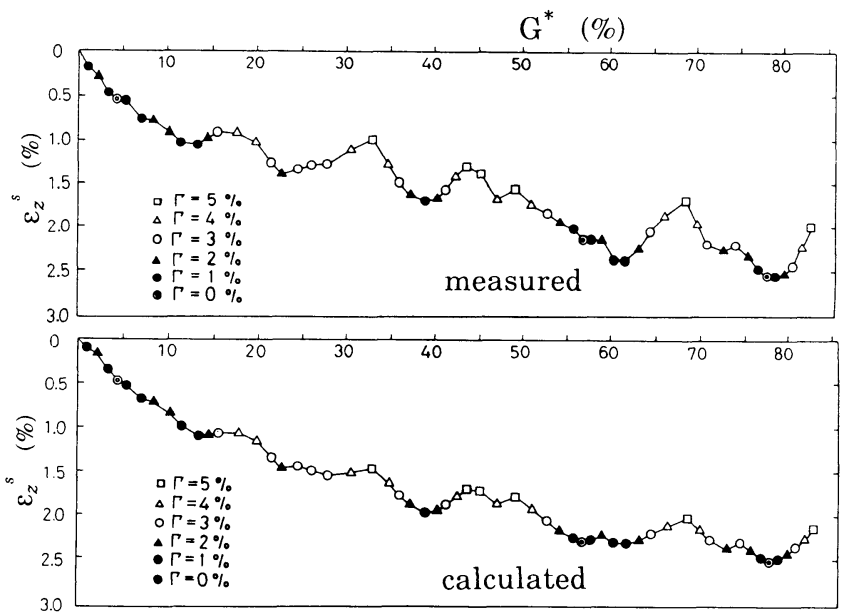

(b) random path

Fig. 21 Comparison of measured values with calculated values of $\varepsilon_{z}^{s}$. 


\section{8. 結 論}

実際の地震時の地盤の挙動を解明するため, 任意方向 にせん断できる単純せん断試験機を用いて種々のせん断 経路の排水せん断試験を行った．そして，これらのダイ レイタンシー特性を統一的に整理するため，累加せん断 ひずみ $G^{*}$ と合せん断ひずみ $\Gamma$ を導入した。その結果, せん断経路のいかんにかかわらず，体積ひずみ $\varepsilon_{z}^{s}$ と $G^{*}$ との間に $\Gamma$ をパラメーターとしたユニークな関係があ ることを見出した．これらのことは，ひずみ空間におい ておわんの形をした斜面が存在し，そのおわんが $G^{*}$ と ともに圧縮してゆくモデルを考えることによって解釈で きた。このモデルにより種々のダイレイタンシーが統一 的に説明できることを示した.

本論文は第一著者が名古屋工業大学修士論文としてま とめたものの一部である.

最後に，この論文を執筆するにあたり，実験等でご援 助いただき有益なご助言を頂いた竹田一夫助手（現・愛 知県庁), 陳 越助教授 (中華人民共和国福州大学), 学 部生 宮林辰雄氏, 森山幸司氏 (現・建設省), 伊藤 学 氏 (現・五洋建設), 三田村裕和氏 (現・日栄建設) に 感謝の意を表します.

\section{参 考 文 献}

1) 軽部大蔵・福岡良武：砂の $X Y$ シンプルシア試験, 昭和 49 年度土木学会関西支部年次学術講演会 III -3, pp. 1 2, 1974

2) Pyke, R., Seed, H. B. and Chan, C. K. : Settlement of sands under multidirectional shaking, JGED, ASCE, Vol. 101, No. GT4, pp.379 398, 1975.
3) Ishihara, K. and Yamazaki, F. : Cyclic simple shear tests on saturated sand in multi-directional loading, Soils and Foundations, Vol. 20, No. 1, pp. 45 59, 1980.

4) Tokimatsu, K. and Yoshimi, Y. : Liquefaction of sand due to multidirectional cyclic shear, Soils and Foundations, Vol. 22, No. 3, pp. 126 130, 1982

5）竹田一夫・松岡 元 - 福武毅芳 : 水平面内全方向単純せ ん断試験機による砂の繰返しせん断特性, 第 38 回土木学 会年次講演会 III - 22, pp. 43 44，1983.

6）松岡 元 - 竹田一夫 - 福武毅芳 - 宮林辰雄 - 森山幸司： 任意方向単純せん断試験における砂の応力・ひずみ挙動, 第 19 回土質工学研究発表会 $118, p p .277 \sim 278,1984$.

7) Chen, Y. and Matsuoka, H. : Analysis of multi-directional simple shear tests on sand, Soils and Found ations, Vol. 25, No.4, pp.147 158, 1985.

8）福武毅芳・松岡 元・竹田一夫・陳 越：任意方向単 純せん断における体積ひずみ特性, 第 39 回土木学会年次 講演会 III - 29 , pp. $57 \sim 58,1984$.

9）松岡 元・福武毅芳・伊藤 学・三田村裕和：任意方向 単純せん断時の砂の応力・ひずみ関係と液状化解析, 第 20 回土質工学研究発表会 118,pp. 287 290, 1985.

10）八木則男：繰返しせん断による砂の体積変化と過剩間腙 水圧, 第 7 回土質工学研究発表会 75, pp. 297 300, 1972.

11) Oh-oka, H. : Drained and undrained stress-strain be havior of sands subjected to cyclic shear stress under nearly plane strain conditions, Soils and Foundations, Vol. 16, No. 3, pp. 19 31, 1976.

12) Matsuoka, H., Koyama, H. and Yamazaki, H. : A constitutive equation of sands and its application to analyses of rotational stress paths and liquefaction resistance, Soils and Foundations, Vol.25, No. 1, pp. 27 $\sim 42,1985$.

（1989.5.31・受付） 